\title{
Seleksi Peserta Didik Baru Menggunakan Metode AHP Dan SAW
}

\author{
Yuniarti Lestari ${ }^{1}$, Sunardi ${ }^{2}$, Abdul Fadlii ${ }^{3}$ \\ ${ }^{1}$ Magister Teknik Informatika, Universitas Ahmad Dahlan Yogyakarta \\ 2,3Teknik Elektro, Universitas Ahmad Dahlan Yogyakarta \\ yuniartilestari85@gmail.com,sunardi@mti.uad.ac.id, fadlil@mti.uad.ac.id
}

\begin{abstract}
The admission activity of new students is an administrative process that is sure to occur every new school year and always repeats every year as a starting point for the search for quality resources in accordance with the criteria of each school. Selection is done manually such as using a spreadsheet or number processor still raises several problems including the length of the selection process. At the time of the participant selection process, it involved many criteria that were assessed (multi criteria). Efforts to assist the school in selecting participants from the results considered to be acceptable results require a decision support system for selecting new students. The method used to support students' selection decisions is AHP and SAW. AHP method is used to determine the weight of predetermined criteria, while the SAW method is used for alternative ranking. The purpose of alternative ranking is who has the right to be accepted as a new student based on predetermined criteria.
\end{abstract}

Keywords: SPK, Selection, criteria, AHP, SAW

\begin{abstract}
Abstrak
Kegiatan penerimaan peserta didik baru merupakan suatu proses administrasi yang pasti terjadi setiap tahun ajaran baru dan selalu berulang setiap tahunnya sebagai titik awal proses pencarian sumber daya yang berkualitas sesuai dengan kriteria masing-masing sekolah. Penyeleksian yang dilakukan secara manual seperti menggunakan spredsheet atau pengolah angka masih menimbulkan beberapa permasalahan antara lain yaitu lamanya proses seleksi. Pada waktu proses pemilihan peserta, melibatkan banyak kriteria-kriteria yang dinilai (multi kriteria). Upaya untuk membantu pihak sekolah dalam memilih peserta dari hasil dipertimbangan menjadi hasil diterima dibutuhkan sistem pendukung keputusan penyeleksian peserta didik baru. Metode yang digunakan untuk mendukung keputusan seleksi peserta didik ini adalah AHP dan SAW. Metode AHP digunakan unyuk menentukan bobot kriteria yang telah ditentukan, sedangkan metode SAW digunakan untuk perangkingan alternatif. Maksud dari perangkingan alternatif adalah siapa yang berhak diterima sebagai peserta didik baru berdasarkan kriteria-kriteria yang telah ditentukan.
\end{abstract}

Kata Kunci : SPK, Seleksi, kriteria, AHP, SAW

\section{PENDAHULUAN}

Kegiatan penerimaan peserta didik baru merupakan suatu proses administrasi yang pasti terjadi setiap tahun ajaran baru. Kegiatan ini selalu berulang setiap tahunnya sebagai titik awal proses pencarian sumber daya yang berkualitas dan sesuai dengan kriteria masing-masing sekolah. Menerima calon peserta didik baru yang sesuai dengan kriteria sekolah dapat menunjang kualitas dan mutu dari sekolah tersebut. Penyeleksian yang dilakukan secara manual seperti menggunakan spredsheet atau pengolah angka masih menimbulkan beberapa permasalahan antara lain yaitu lamanya proses seleksi. Lama proses seleksi tersebut bisa memakan waktu kurang 
lebih satu bulan. Lamanya proses seleksi tersebut disebabkan karena lamanya proses memilih dari hasil pertimbangan yang ada menjadi hasil diterima. Proses ini memerlukan kehati-hatian dan ketelitian karena peserta yang dipilih harus berkualitas sesuai dengan kriteria-kriteria yang telah ditentukan, sehingga daya tampung atau kuota peserta didik dapat terpenuhi semuanya.

Pada waktu proses pemilihan peserta melibatkan banyak kriteriakriteria yang dinilai (multi kriteria). Upaya untuk membantu pihak sekolah dalam memilih peserta dari hasil dipertimbangan menjadi hasil diterima dibutuhkan sistem pendukung keputusan penyeleksian peserta didik baru. Metode yang digunakan untuk mendukung keputusan seleksi peserta didik ini adalah AHP dan SAW. Metode AHP digunakan unyuk menentukan bobot kriteria yang telah ditentukan, sedangkan metode SAW digunakan untuk perangkingan alternatif. Maksud dari perangkingan alternatif adalah siapa yang berhak diterima sebagai peserta didik baru berdasarkan kriteriakriteria yang telah ditentukan. Penelitian ini diharapkan dapat menghasilkan perancangan sistem seleksi penerimaan peserta didik baru yang memudahkan dalam proses penerimaan peserta didik baru dengan menerapkan metode AHP dan SAW dalam pengambilan keputusan.

\section{METODOLOGI PENELITIAN}

\subsection{Metode Analytical Hierarchy Process (AHP)}

Metode AHP merupakan metode pendukung pengambilan keputusan yang dikembangkan oleh Thomas L., Saaty pada tahun 1980. AHP merupakan alat untuk pengambil keputusan yang menguraikan suatu permasalahan kompleks dalam struktur hirarki dengan banyak tingkatan yang terdiri atas tujuan, kriteria dan alternatif. Hirarki merupakan suatu representasi dari suatu permasalahan yang kompleks dalam suatu struktur multi level dimana level pertama adalah tujuan yang diikuti level faktor, kriteria, sub kriteria, dan seterusnya ke bawah hingga level terakhir dari alternative.

Metode AHP menggunakan beberapa tahap yang harus dilakukan dalam penggunaannya. Tahapan - tahapan itu antara lain :

a) Penyusunan hirarki permasalahan yang ada

b) Penentuan prioritas elemen

Langkah - langkahnya sebagai berikut:

1) Pembuatan matrik berpasangan

2) Pengisian matrik berpasangan

3) Sintesis

\subsection{Metode Simple Additive Weighting (SAW)}

Metode SAW merupakan metode penjumlahan terbobot dari sebuah rating kinerja tiap alternatif untuk semua atribut. Metode ini membutuhkan proses normalisasi matrik keputusan $(\mathrm{x})$ ke bentuk skala yang bisa 
diperbandingkan dengan rating alternatif yang ada. Pada tahap ini penulis menerapkan metode SAW untuk perangkingan alternatif. Berikut ini merupakan persamaan sebagai SAW :

$$
\begin{aligned}
& r i j=\frac{X i j}{\operatorname{Max} X i j} \text { Jika } \mathrm{j} \text { atribut keuntungan (benefit) } \\
& r i j=\frac{\operatorname{Min} X i j}{X i j} \quad \text { Jika } \mathrm{j} \text { atibut biaya (cost) }
\end{aligned}
$$

rij merupakan rating kinerja ternormalisasi untuk alternatif Ai pada atribut $\mathrm{Cj} ; \mathrm{i}=1,2, \ldots, \mathrm{m}$ dan $\mathrm{j}=1,2, \ldots, \mathrm{n}$. Nilai preferensi setiap alternatif $(\mathrm{Vi})$ sebagai berikut :

$$
V i=\sum_{j=1}^{n} w j r i j
$$

Keterangan :

$$
\begin{aligned}
\mathrm{Vi} & =\text { nilai prefensi } \\
\mathrm{wj} & =\text { bobot rangking } \\
\mathrm{rij} & =\text { rating kinerja ternormalisasi }
\end{aligned}
$$

Jika Vi yang lebih besar ada indikasi bahwa alternatif Ai akan lebih terpilih. Langkah - langkah dari metode SAW adalah :

a) Menentukan kriteria yang dijadikan acuan untuk pengambilan keputusan yaitu $\mathrm{Cj}$.

b) Memberikan rating kecocokan untuk setiap alternatif pada semua kriteria.

c) Membuat matriks keputusan (x) berdasarkan pada kriteria (C), kemudian melakukan langkah normalisasi matriks berdasarkan persamaan yang sudah disesuaikan dengan jenis atribut baik atribut keuntungan ataupun atribut biaya sehingga diperoleh matriks ternormalisasi R.

d) Hasil akhir akan diperoleh dari proses perankingan yaitu penjumlahan dari perkalian matriks ternormalisasi $\mathrm{R}$ dengan vector bobot sehingga diperoleh nilai terbesar yang dipilih sebagai alternatif terbaik (A) sebagai solusi.

\section{HASIL DAN PEMBAHASAN}

\subsection{Penggunaan Metode AHP dan SAW}

Sekolah akan menyeleksi siswa berdasarkan 4 kriteria yaitu NUN, NUS, TPA dan jalur masuk. Jalur masuk akan dibagi dalam tiga 3 kriteria jalur, yaitu jalur NUN dengan kuota 60\%, jalur miskin dengan kuota 20\% dan jalur prestasi dengan kuota 20\%. Berdasarkan analisis masalah di atas maka solusi yang diusulkan adalah pemanfaatkan perkembangan teknologi yaitu sebuah perangkat lunak sistem pendukung keputusan berbasis web yang akan digunakan sebagai pendukung pengambilan keputusan menggunakan berbagai metode. Metode yang digunakan dalam penelitian ini adalah Metode 
SAW untuk penyeleksian dan metode AHP untuk penentukan bobot awal masing-masing kriteria.

\subsection{Pembobotan Menggunakan AHP}

Berikut ini merupakan langkah - langkah untuk penentuan bobot menggunakan AHP:

\section{a. Membuat Matrik Perbandingan Berpasangan}

Matrik perbandingan berpasangan pada tabel 1 menggunakan skala penilaian perbandingan. Kemudian Cij diisi menggunakanpersamaan (1-1).

Tabel 1. Matriks Perbandingan Berpasangan

\begin{tabular}{|l|c|c|c|c|}
\hline \multicolumn{1}{|c|}{ Kriteria } & NUN & NUS & TPA & Ialur Masuk \\
(C1) & (C2) & (C3) & (C4) \\
\hline NUN (C1) & 1 & 2 & 3 & 4 \\
\hline NUS (C2) & Cij & 1 & 3 & 4 \\
\hline TPA (C3) & Cij & Cij & 1 & 3 \\
\hline Ialur Masuk (C4) & Cij & Cij & Cij & 1 \\
\hline
\end{tabular}

\section{b. Memenuhi Kolom Matriks Perbandingan Berpasangan}

Memasukkan rasio kepentingan (skala kuantitatif) akan mendapatkan matriks perbandingan berpasangan penuh seperti pada tabel 2 berikut ini.

Tabel 2. Matriks Perbandingan Berpasangan Penuh

\begin{tabular}{|l|c|c|c|c|}
\hline \multicolumn{1}{|c|}{ Kriteria } & $\begin{array}{c}\text { NUN } \\
\text { (C1) }\end{array}$ & $\begin{array}{c}\text { NUS } \\
\text { (C2) }\end{array}$ & $\begin{array}{c}\text { TPA } \\
\text { (C3) }\end{array}$ & $\begin{array}{c}\text { Ialur Masuk } \\
\text { (C4) }\end{array}$ \\
\hline NUN (C1) & 1 & 2 & 3 & 4 \\
\hline NUS (C2) & 0,5 & 1 & 3 & 4 \\
\hline TPA (C3) & 0,333 & 0,333 & 1 & 3 \\
\hline Jalur Masuk (C4) & 0,25 & 0,25 & 0,333 & 1 \\
\hline Iumlah & 2,083 & 3,583 & 7,333 & 12 \\
\hline
\end{tabular}

Jumlahkan hasil penilaian pada setiap kolom dan dilanjutkan membuat matriks ternormalisasi.

\section{c. Normalisasi Matriks}

Normalisasi matrik dilakukan dengan cara membagi setiap elemen pada kolom dengan jumlah per kolom yang sesui. Penghitungan normalisasi dapat dilakukan dengan cara berikut :

$$
m=\frac{x_{i j}}{n}
$$

Keterangan :

$$
\begin{array}{ll}
\mathrm{m} & =\text { hasil normalisasi } \\
\mathrm{x} & =\text { nilai tiap cell / gabungan antara baris dan kolom } \\
\mathrm{n} & =\text { hasil jumlah tiap kolom }
\end{array}
$$

Contoh perhitungan : 


$$
\begin{aligned}
& \mathrm{m}_{11}=1 / 2,083=0,480 \\
& \mathrm{~m}_{12}=0,5 / 2,083=0,240 \\
& \mathrm{~m}_{13}=0,33 / 2,083=0,160 \\
& \mathrm{~m}_{14}=0,25 / 2,083=0,120
\end{aligned}
$$
tabel 3.

Berikut ini hasil dari nilai normalisasi matriks yang dapat dilihat pada

Tabel 3. Matriks Ternormalisasi

\begin{tabular}{|l|c|c|c|c|c|}
\hline \multicolumn{1}{|c|}{ Kriteria } & $\begin{array}{c}\text { NUN } \\
\text { (C1) }\end{array}$ & $\begin{array}{c}\text { NUS } \\
\text { (C2) }\end{array}$ & $\begin{array}{c}\text { TPA } \\
\text { (C3) }\end{array}$ & $\begin{array}{c}\text { Jalur Masuk } \\
(\mathrm{C} 4)\end{array}$ & Jumlah \\
\hline NUN (C1) & 0,480 & 0,558 & 0,409 & 0,333 & 1,780 \\
\hline NUS (C2) & 0,240 & 0,279 & 0,409 & 0,333 & 1,261 \\
\hline TPA (C3) & 0,160 & 0,093 & 0,136 & 0,250 & 0,639 \\
\hline Ialur Masuk (C4) & 0,120 & 0,069 & 0,045 & 0,083 & 0,138 \\
\hline
\end{tabular}

\section{d. Pembobotan/Prioritas}

Pembobotan dilakukan dengan cara membagi masing - masing jumlah baris dengan jumlah elemen atau jumlah kriteria. Berikut rumus untuk menghitung bobot prioritas :

$$
b p=\frac{\sum_{j=0}^{n} x_{i j}}{n}
$$

Keterangan :

$\mathrm{bp}=$ hasil rata-rata/bobot prioritas

$\mathrm{n}=$ banyak kriteria

$\mathrm{j}=1,2,3, \ldots, \mathrm{n}$

$\mathrm{x}=$ nilai tiap cell / gabungan antara baris dan kolom

Contoh perhitungan :

$$
\begin{aligned}
& \text { Bp C }_{1}=(0,480+0,558+0,409+0,333) / 4=1,780 / 4=0,445 \\
& \text { Bp C }_{2}=(0,240+0,279+0,409+0,333) / 4=1,261 / 4=0,315 \\
& \text { Bp C }_{3}=(0,160+0,093+0,136+0,250) / 4=0,639 / 4=0,159 \\
& \text { Bp C }_{4}=(0,120+0,069+0,045+0,083) / 4=0,318 / 4=0,079
\end{aligned}
$$

Tabel 4 merupakan hasil dari pembobotan yang dilakukan.

Tabel 4. Bobot Prioritas

\begin{tabular}{|l|l|}
\hline \multicolumn{1}{|c|}{ Kriteria } & Bobot \\
\hline NUN & 0,445 \\
\hline NUS & 0,315 \\
\hline TPA & 0,159 \\
\hline Jalur Masuk & 0,079 \\
\hline
\end{tabular}

\section{e. Menghitung Eigen maksimum}


Proses pembuatan keputusan, penting untuk mengetahui seberapa baik konsistensi yang ada karena tidak diharapkan keputusan berdasarkan pertimbangan dengan konsistensi yang rendah. Hal-hal yang dilakukan dalam tahap ini adalah :

1) Kalikan setiap nilai cell pertama dengan bobot prioritas pertama

Nilai pada kolom cell kedua dengan prioritas kedua, dan seterusnya.

Contoh perhitungan:

Kolom NUN $=1 * 0,445=0,445$

Kolom NUS $=2 * 0,315=0,630$

Kolom TPA $=3 * 0,160=0,480$

Kolom Jalur Masuk $=4 * 0,079=0,316$

Lakukan perhitungan sampai kolom terakhir. Berikut hasil dari perkalian setiap nilai cell dengan bobot prioritas dapat dilihat pada tabel 5 .

Tabel 5. Perkalian Setiap Nilai Cell Dengan Bobot Prioritas

\begin{tabular}{|l|c|c|c|c|}
\hline \multicolumn{1}{|c|}{ Kriteria } & NUN & NUS & TPA & Jalur Masuk \\
\hline NUN & 0,445 & 0,630 & 0,480 & 0,316 \\
\hline NUS & 0,223 & 0,315 & 0,480 & 0,316 \\
\hline TPA & 0,148 & 0,104 & 0,160 & 0,237 \\
\hline Jalur Masuk & 0,111 & 0,078 & 0,053 & 0,079 \\
\hline
\end{tabular}

2) Jumlahkan hasilnya untuk setiap baris pada matriks.

Contoh perhitungan:

Baris Golongan $=0,445+0,630+0,480+0,316=1,871$

Lakukan perhitungan sampai baris terakhir atau baris minat. Berikut hasil penjumlahan setiap baris pada matriks dapat dilihat pada tabel 6 .

Tabel 6. Hasil Penjumlahan Setiap Baris

\begin{tabular}{|l|c|c|c|c|c|}
\hline \multicolumn{1}{|c|}{ Kriteria } & NUN & NUS & TPA & Jalur Masuk & Jumlah \\
\hline NUN & 0,445 & 0,630 & 0,480 & 0,316 & 1,871 \\
\hline NUS & 0,223 & 0,315 & 0,480 & 0,316 & 1,334 \\
\hline TPA & 0,148 & 0,104 & 0,160 & 0,237 & 0,649 \\
\hline Jalur Masuk & 0,111 & 0,078 & 0,053 & 0,079 & 0,321 \\
\hline
\end{tabular}

3) Hasil dari penjumlahan baris dibagi dengan elemen prioritas yang bersangkutan.

Contoh perhitungan:

Baris Golongan $=1,871 / 0,445=4,204$

Lakukan perhitungan sampai baris terakhir atau baris minat. Berikut hasil penjumlahan baris dibagi dengan elemen prioritas baris dapat dilihat pada tabel 7. 
Tabel 7. Hasil Penjumlahan Baris Dibagi Dengan Elemen Prioritas

Baris

\begin{tabular}{|l|c|c|c|}
\hline \multicolumn{1}{|c|}{ Kriteria } & Jumlah & Bobot & $\boldsymbol{\chi}$ \\
\hline NUN & 1,871 & 0,445 & 4,204 \\
\hline NUS & 1,334 & 0,315 & 4,234 \\
\hline TPA & 0,649 & 0,159 & 4,081 \\
\hline Jalur Masuk & 0,321 & 0,079 & 4,063 \\
\hline
\end{tabular}

4) Jumlahkan hasil lamda tiap kriteria dibagi dengan banyak elemen yang ada, hasilnya disebut $\chi m a z$ yang ditunjukkan pada persamaan dibawah ini.

$$
\lambda_{\text {maks }}=\frac{\sum \lambda}{n}
$$

Keterangan:

入maks = eigen maksimum

$\mathrm{n}=$ banyak kriteria

Contoh perhitungan :

$\lambda=4,204+4,234+4,081+4,063=16,582$

$\lambda$ maks $=16,582 / 4=4,145$

5) Menghitung Indek Konsistensi atau Consistency Index (CI) yang ditunjukkan pada persamaan dibawah ini.

$$
C I=\frac{\lambda_{\text {maks }}-n}{n-1}
$$

Keterangan:

$$
\mathrm{n}=\text { banyak elemen }
$$

Contoh perhitungan:

$\mathrm{CI}=(4,145-4) /(4-1)=0,145 / 3=0.048$

6) Menghitung Rasio Konsistensi atau Consistency Ratio (CR) yang ditunjukkan pada persamaan dibawah ini.

$$
C R=\frac{C I}{R I}
$$

Keterangan:

$$
\begin{aligned}
& \mathrm{RI}=\text { rasio indeks } \\
& \mathrm{CR}=\text { rasio konsistensi }
\end{aligned}
$$

Contoh perhitungan:

$\mathrm{CR}=0.048 / 0,90=0.053$

7) Iika nilai $C R>0,1$ maka penilaian data judgement tidak konsisten dan harus diperbaiki. Iika rasio konsisten $\mathrm{CR}<=0,1$ maka perhitungan data konsisten dan benar. CR yang didapatkan 0,053 menunịukkan $\mathrm{CR}<=0,1$ 
maka perhitungan data konsisten dan benar. Kemudian bobot selanjutnya digunakan untuk perhitungan SAW.

\subsection{Perangkingan Menggunakan SAW}

Berikut ini langkah-langkah penghitungan menggunakan metode SAW:

\section{a) Matriks Keputusan}

Tabel 8. Matrik Keputusan

\begin{tabular}{|l|c|c|c|c|}
\hline Kriteria & C1 & C2 & C3 & C4 \\
\hline IPA & 80 & 85 & 70 & 1 \\
\hline IPS & 90 & 90 & 80 & 3 \\
\hline Bahasa & 85 & 95 & 85 & 2 \\
\hline
\end{tabular}

Keterangan:

C1 : Nilai Ujian Nasional SMP / MTs (data asli)

C2 : Nilai Ujian Sekolah SMP / MTs (data asli)

C3 : TPA

C4 : Jalur Masuk dengan ketentuan : 3=reguler, $2=$ prestasi, 1=miskin Berikut ini merupakan matriks keputusan (X) :

$$
X=\left(\begin{array}{llll}
80 & 85 & 70 & 1 \\
90 & 90 & 80 & 3 \\
85 & 95 & 85 & 2
\end{array}\right)
$$

\section{b) Normalisasi Matrik}

$$
r i j=\frac{x_{i j}}{\operatorname{Max}_{i} x_{i j}}
$$

Normalisasi matrik dengan acuan bahwa semua atribut merupakan keuntungan atau benefit.

$\begin{array}{lll}\text { IPA } & r_{11}=80 / \max (80+90+85)=80 / 90=0,89 \\ & r_{12}=85 / \max (85+90+95)=85 / 95=0,89 \\ & r_{13}=70 / \max (70+80+85)=70 / 85=0,82 \\ \text { IPS } & r_{14}=1 / \max (1+3+2)=1 / 3=0.33 \\ & r_{21}=90 / \max (80+90+85)=90 / 90=1 \\ & r_{22}=90 / \max (85+90+95)=90 / 95=0,95 \\ & r_{23}=80 / \max (70+80+85)=80 / 85=0,94 \\ \text { Bahasa } & r_{24}=3 / \max (1+3+2)=3 / 3=1 \\ & r_{31}=85 / \max (80+90+85)=85 / 90=0,94 \\ & r_{32}=95 / \max (85+90+95)=95 / 95=1 \\ & r_{33}=85 / \max (70+80+85)=85 / 85=1 \\ & r_{34}=2 / \max (1+3+2)=2 / 3=0,67\end{array}$




$$
X=\left(\begin{array}{lccc}
0,89 & 0,89 & 0,82 & 0,33 \\
1 & 0,95 & 0,94 & 1 \\
0,94 & 1 & 1 & 0,67
\end{array}\right)
$$

\section{c) Perangkingan}

Proses perangkingan menggunakan persamaaan :

$$
v_{i}=\sum_{j=1}^{n} w_{j} r_{i j}
$$

Bobot dari perhitungan AHP :

$\begin{array}{lc}\text { Kriteria } & \text { Bobot } \\ \text { NUN } & 0,445 \\ \text { NUS } & 0,315 \\ \text { TPA } & 0,159 \\ \text { Jalur Masuk } & 0,079\end{array}$

Melakukan perkalian matrik normalisasi dengan matrik bobot :

$$
\begin{aligned}
\mathrm{V} 1 & =(0,89 \times 0,445)+(0,89 \times 0,315)+(0,82 \times 0,159)+(0,33 \times 0,159) \\
& =0,396+0,280+0,130+0,052=0,858 \\
\mathrm{~V} 2 & =(1 \times 0,445)+(0,95 \times 0,315)+(0,94 \times 0,159)+(1 \times 0,159) \\
& =0.445+0,299+0,149+0,159=1,052 \\
\mathrm{~V} 3 & =(0,94 \times 0,445)+(1 \times 0,315)+(1 \times 0,159)+(0,67 \times 0,159) \\
& =0,418+0,315+0,159+0,107=0,999
\end{aligned}
$$

Dari perhitungan yang dilakukan akan mendapatkan hasil perangkingan siswa. Perangkingan siswa pada jalur ini dibedakan berdasarkan jenis j̣urusan yang dipilih, hasilnya menịadi seperti berikut:

$$
\begin{array}{ll}
\text { IPA } & \text { V1 }=0,858 \\
\text { IPS } & \text { V2 }=1,052 \\
\text { Bahasa } & \text { V3 }=0,999
\end{array}
$$

Hasil akhir yang diperoleh dari perangkingan yaitu peserta didik tersebut dimasukkan ke peminatan IPS.

\subsection{Analisis Kebutuhan Perangkat Lunak}

Berdasarkan analisis terhadap sistem pendukung keputusan seleksi penerimaan peserta didik baru ada beberapa proses yang dapat diimplementasikan. Proses tersebut antara lain sebagai berikut :
a) Proses mengelola data peserta didik
b) Proses mengelola data orang tua
c) Proses mengelola data kriteria
d) Proses mendapatkan data bobot awal menggunakan metode AHP
e) Proses mengelola nilai peserta didik jalur nun
f) Proses mengelola nilai peserta didik jalur miskin 
g) Proses mengelola nilai peserta didik jalur prestasi akademik

h) Proses mengelola nilai peserta didik jalur prestasi non akademik

i) Proses melakukan penyeleksian menggunakan metode SAW

j) Proses memberikan rekomendasi peserta didik yang diterima beserta penjurusan secara langsung

k) Proses mencetak laporan

\subsection{DFD level 0}

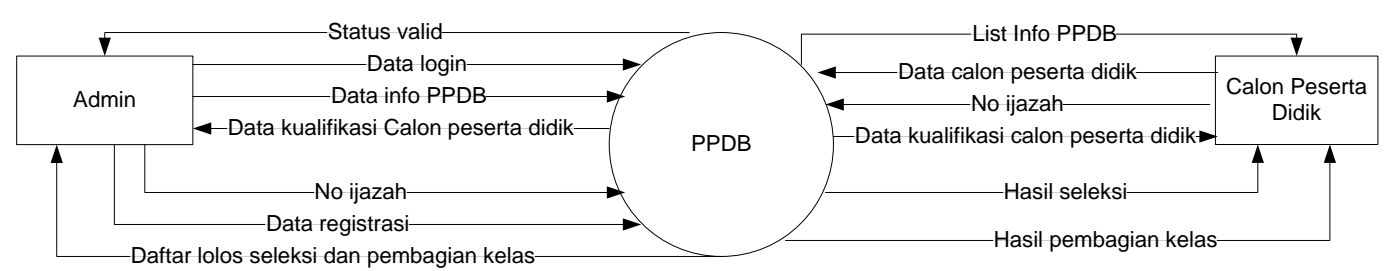

Gambar 1. DFD level 0 Sistem Penerimaan Peserta Didik Baru

\subsection{Relasi Antar Tabel}

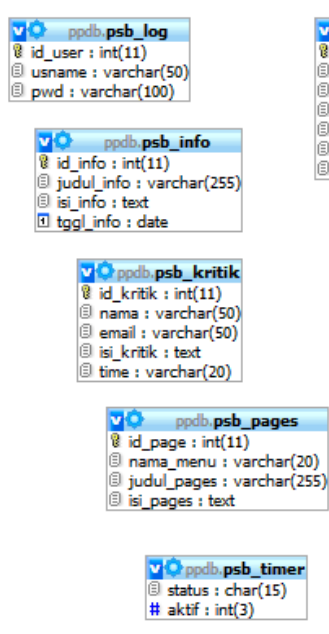

VO podb.psb_time
$\begin{aligned} & \text { O status : char(15) } \\ & \text { \# aktif : int(3) }\end{aligned}$
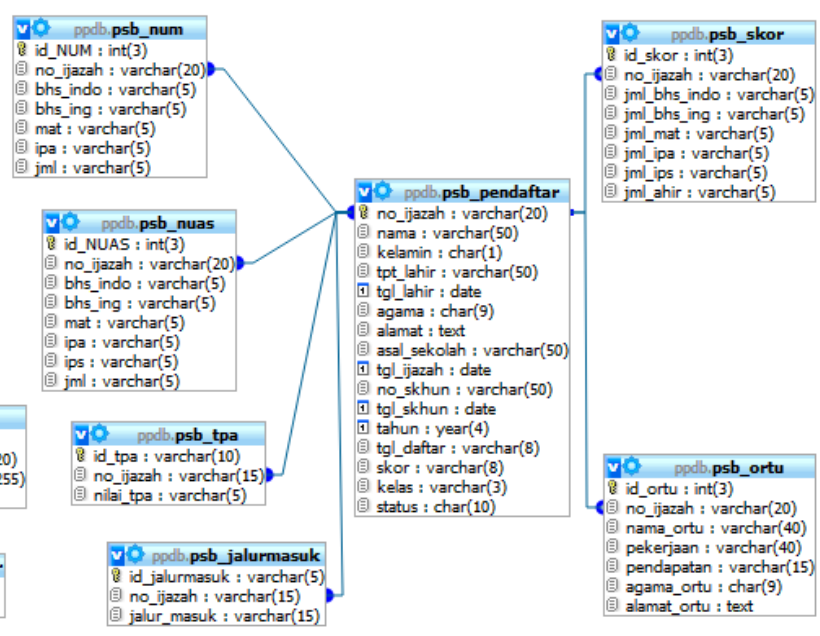
agama_ortu : char( $(9)$
alamat_ortu : text

Gambar 2. Relasi Antar Tabel

\section{SIMPULAN}

a) Sistem pendukung keputusan seleksi penerimaan peserta didik dapat membantu dan mempermudah dalam proses seleksi penerimaan peserta didik SMA yang sebelumnya masih dilakukan secara manual.

b) Metode Analytic Hierarchy Process (AHP) dan Simple Additive Weighting (SAW) dapat diterapkan pada sistem pendukung keputusan seleksi penerimaan peserta didik SMA untuk memberikan alternatif hasil perangkingan dan penentuan alternatif yang memiliki preferensi terbaik dari alternatif yang lain. 


\section{DAFTAR PUSTAKA}

[1] Dian Purwitasari, Kitnas \& Feddy Setio Pribadi. 2015. Implementasi Sistem Pendukung Keputusan Peminatan Peserta Didik SMA menggunakan Metode AHP (Analytic Hierarchy Process) dan SAW (Simple Additive Weighting).Jurnal Teknik Elektro Vol. 7 No. 2 Juli-Desember 2015.

[2] Irawan, Yan \& Delpiah Wahyuningsih. 2018. Pendaftaran Peserta Didik Baru Dengan Metode Simple Additive Wighting (SAW). Jurnal Sistem Informasi Volume.5 No.1, Maret 2018 p-ISSN: 2406-7768 e-ISSN: 2581-2181.

[3] Putra, Putu Angga Septiana, I Made Agus Wirawan \& I made Gede Sunarya. 2016. Pengembangan Sistem Pendukung Keputusan Penerimaan Siswa Baru Di Sma Negeri 1 Seririt Dengan Metode Simple Additive Weighting (SAW) Dan Metode AnalyticalHierarchy Process (AHP). Kumpulan Artikel Mahasiswa Pendidikan Teknik Informatika (KARMAPATI) Volume 5, Nomor 1, Januari 2016 ISSN 2252-9063.

[4] Permatasari, Diah, Dewi Sartika \& Suryati. 2018. Penerapan Metode AHP dan SAW Untuk Penentuan Kenaikan Jabatan Karyawan. Jurnal Teknik Informatika dan Sistem Informasi Vol. 5, No. 1, September 2018, Hal. 60-73 ISSN 24074322 E-ISSN 2503-2933.

[5] Amin, Ruhul. 2017. Rancang Bangun Sistem Informasi Penerimaan Siswa Baru Pada SMK Budhi Warman 1 Jakarta VOL. 2. NO. 2 Februari 2017 E-ISSN: 25274864.

[6] Mubarok, Farid. Harliana \& Ijah Hadijah. 2015. Perbandingan Antara Metode RUP dan Prototype Dalam Aplikasi Penerimaan Siswa Baru Berbasis Web. Citec Journal, Vol. 2, No. 2, Februari 2015 - April 2015 ISSN: 2354-5771.

[7] Muhidin, Rusli. N Faisal Kharie \& Muin Kubais. 2017. Analisis Dan Perancangan Sistem Informasi Pada Sma Negeri 18 Halmahera Selatan Sebagai Media Promosi Berbasis Web. Volume 2 Nomor 2 | April 2017 ISSN 2548-6438.

[8] Setiawan, Adil. 2017. Implementasi Metode SAW Dalam Penerimaan Siswa Baru pada SMA Negeri 16 Medan. Jurnal Riset Sistem Informasi Dan Teknik Informatika (JURASIK) Volume (2) No. 1 Juli 2017 ISSN: 2527-5771/EISSN: 2549-7839

[9] Patta, Abdul Rahim. 2016. Pengembangan Sistem Informasi Penerimaan Siswa Baru Berbais WEB dan SMS Gateway 22(10), pp. 1066-1077.

[10] Palilingan, Kenneth Y. R. 2014. Registrasi Calon Siswa Baru Berbasis Mobile Android Di SMA N 9 Manado ISSN: 2301-8402.

[11] Sudrajad, Untung. 2014. Pengelolaan penerimaan peserta didik baru di SMP Negeri 2 Wonogiri. Magister Manajemen Pendidikan Program Pascasarjana Universitas Muhammadiyah Surakarta : Surakarta.

[12] Purnama, Joni. 2016. Sistem Pendukung Keputusan Seleksi Penerimaan Siswa Baru Menggunakan Metode Simple Additive Weighting (Saw) (Studi Kasus : Sma Negeri 01 Kalirejo).

[13] Fawaid, Ardian \& Anggraini Mulwinda. 2013. Sistem Pendukung Keputusan Penerimaan Peserta Didik Baru Menggunakan Metode Analytical Hierarchy Process.

[14] Ananda, Dea Trisna. 2016. Sistem Pendukung Keputusan Pada Seleksi Penerimaan Siswa Sekolah Menengah Kejuruan. Universitas Lampung : Lampung. 